\title{
Kafa kaidesi kırığına bağlı pnömokok menenjiti sekeli olarak gelişen serebral enfarktüs olgusu
}

\section{Cerebral infarctus developed as a sequelae of Pneumococcal meningitis in an operated case with skull base fracture}

Tuba İLAR, Özlem ÖZEL, Çiğdem ATAMAN HATiPOĞLU, Salih CESUR*, Esra KAYA KILIÇ, Sami KINIKLI, Ali Pekcan DEMiRÖZ

Ankara Eğitim ve Araştırma Hastanesi, Enfeksiyon Hastalıkları ve Klinik Mikrobiyoloji Kliniği, Ankara, TÜRKIYE

\begin{abstract}
öz
Kafa travmaları ve kafa kemiği kırıklarından sonra rinore ve otore görülebilir. Kafa kaidesi kırıklarından sonra hastalarda rekürren menenjitlere en sık neden olan etken Streptococcus pneumoniae'dır. Bu yazıda kafa kaidesi kırı̆ı̆ı nedeniyle opere edilen ve pnömokok aşısı uygulanmayan ve reküren pnömokok menenjiti gelişen 65 yaşında bir erkek olgu sunulmuştur. Olguda pnömokok menenjit sonrasında sekel olarak akut/subakut serebral infarktüs gelişmiştir. Kafa kaidesi kırığı, rinore ve otoresi olan hastalarda pnömokokal menenjit gelişiminin önlenmesi için hastalara mutlaka pnömokok aşısının uygulanması uygun yaklaşımdır.
\end{abstract}

Anahtar Kelimeler: Menenjit, Streptococcus pneumoniae, komplikasyon, serebral enfarkt

\section{ABSTRACT}

After head trauma and fractures, rhinorrhea and otorrhea can be occured. Streptococcus pneumoniae is the most frequent cause of recurrent meningitis in patients with scull base fractures. In this article, a 65-year-old male who was operated for scull base fracture and was not vaccinated for pneumococcus and was diagnosed as a recurrent pneumococcal meningitis was reported. In the case, acute/subacute cerebral infarctus developed as a sequelae after pneumococcal meningitis. In order to prevent the development of pneumococcal meningitis in patients with skull base fracture, rhinorrhea and otorrhea; the administration of pneumococcal vaccination are suitable approaches.

Keywords: Meningitis, Streptococcus pneumoniae, complication, cerebral infarction

Corresponding Author*: Salih CESUR, MD. Sağlık Bakanlığı Ankara Eğitim ve Araştırma Hastanesi, Enfeksiyon Hastalıkları ve Klinik Mikrobiyoloji Kliniği, Ulucanlar Cad, Altındağ, Ankara, TÜRKiYE

e-mail: scesur89@yahoo.com

Doi. 10.18663/tjcl.285152

Received 10.01.2017 accepted 10.03.2017 


\section{Giriş}

Akut bakteriyel menenjit olgularının \%80-85 kadarından Streptococcus pneumoniae (S. pneumoniae), Neisseria meningitidis ve Haemophilus influenzae sorumludur, ancak belirli yaş gruplarında ve bazı predispozan durumlarda etkenlerin görülme sıklığı değişiklik gösterir. Elli yaş üzeri hastalarda bu etkenlere ek olarak Listeria monocytogenes ve Gram negatif basiller de görülmektedir [1].

Pnömokok menenjitlerinde mortalite oranı diğer bakteriyel menenjitlere göre daha yüksektir. Pnömokok menenjitine bağlı olarak ölümler 60 yaş altında sık görülürken, nörolojik komplikasyonlar 60 yaşından büyük hastalarda daha sık görülür. Kafa kaidesi kırığı ve bunun sonucunda gelişen BOS sızıntısı tekrarlayan pnömokok menenjitleri için en önemli predispozan faktördür [2]. Bu yazıda kafa kaidesi kırığı ameliyatı olmuş, daha önce pnömokok aşısı olmamış 65 yaşında bir erkek hastada pnömokok menenjiti tedavisi sonrasında sekel olarak serebral enfarktüs gelişimi bildirilmiştir.

\section{Olgu}

Altmış beş yaşında erkek hasta; karın ağrısı, bulantı-kusma şikayetleri ile acil servise getirilmişti. Hastanın anamnezinden 8 yıl önce kafa kaidesi kırığı nedeniyle opere edildiği, arada anlamsız konuşmaları ve burun akıntısının olduğu, pnömokok aşısının yapılmadığı öğrenildi. Fizik muayenesinde vücut ısısı 39,5 ${ }^{\circ} \mathrm{C}$ ve bilinci kapalı idi. Ense sertliği ve Brudzinski pozitif idi La-

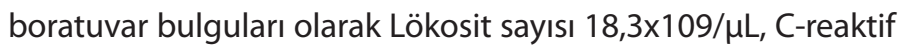
protein (CRP) 3,98 mg/dL (N:0-0,8), eritrosit sedimentasyon hızı (ESH) $16 \mathrm{~mm} / \mathrm{s}$ (N:0-15) saptandı. Hasta acilde iki kez jeneralize tonik klonik nöbet geçirdi. Bilgisayarlı beyin tomografisinde sağ frontotemporalde ensefalomalezik doku alanları görüldü, kanama-kitle görülmedi. Göz dibi muayenesinde papil ödem saptanmadı, lomber ponksiyon yapıldı. Beyin omurilik sıvısı (BOS) mikroskopisinde 280 lökosit (\%100 PMNL) görüldü. Gram boyamasında mikroorganizma görülmedi. BOS biyokimyasında protein 5016 mg/L (N:150-450), glukoz < 10 mg/dL saptandı. Bakteriyel menenjit ön tanısıyla kliniğimize yatıııldı. Seftriakson

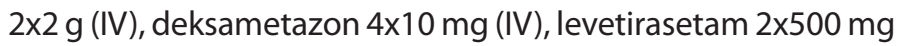
(IV) tedavileri başlandı. Yatışının 2. gününde solunum sıkıntısı oldu, entübe edildi ve yoğun bakım ünitesine devredildi. Lö-

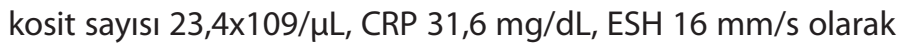
belirlendi. Akciğer grafisinde bilateral yaygın infiltrasyon görülmesi, genel durumunun kötüleşmesi, septik durum (SIRS kriterlerinin saptanması üzerine) gelişmesi üzerine, seftriakson kesilip meropenem $3 \times 2 \mathrm{~g}$ (IV) tedavisi başlandı.

BOS kültüründe Streptococcus pneumoniae üredi. Penisilin minimal inhibitör konsantrasyon (MiK) değeri $0,047 \mathrm{mg} / \mathrm{L}$ saptandı. Hastanın genel durumunun aniden kötüleşmesi ve solunum sıkıntısı başlaması nedeniyle nozokomiyal pnömoni düşünülmemesine rağmen meropenem tedavisine devam edildi. Toplum kaynaklı pnömoni olmadığı nasıl anlaşıldı. Yatı- şının ertesi günü solunum sıkıntısı başlamış. Hastane kaynaklı pnömoni olmayabilir mi düşüncesiyle meropenem tedavisine devam edildi. Yatışııın 10. gününde kontrastlı kraniyal MR görüntülemesinde sağ frontopariyetotemporalde kortikal-subkortikal alanları etkileyen kistik ensefalomalazik doku alanı; bilateral serebral hemisferlerde yaygın olarak izlenen kontrast tutulumu görüldü, menenjitle uyumlu olabileceği düşünüldü. Ensefalomalazik doku alanı çevresinde difüzyon kısıtlaması gösteren fokal doku alanları görüldü, akut-subakut enfarktla uyumlu olarak değerlendirildi ( Resim 1).

Tedavinin 6. gününde solunum sıkıntısı geriledi, bilinci açıldı ve ekstübe edildi. Meropenem tedavisinin 14. gününde akciğerde infiltrasyonda azalma olduğu görüldü (Resim 2, 3). Lö-

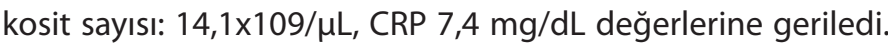
Hastaya konjuge pnömokok aşısı yapıldı. Yatışı süresince ateşi olmayan, bilinci açılan hastanın antibiyotik tedavisi 14 güne tamamlandı, kontrole gelmek üzere taburcu edildi.

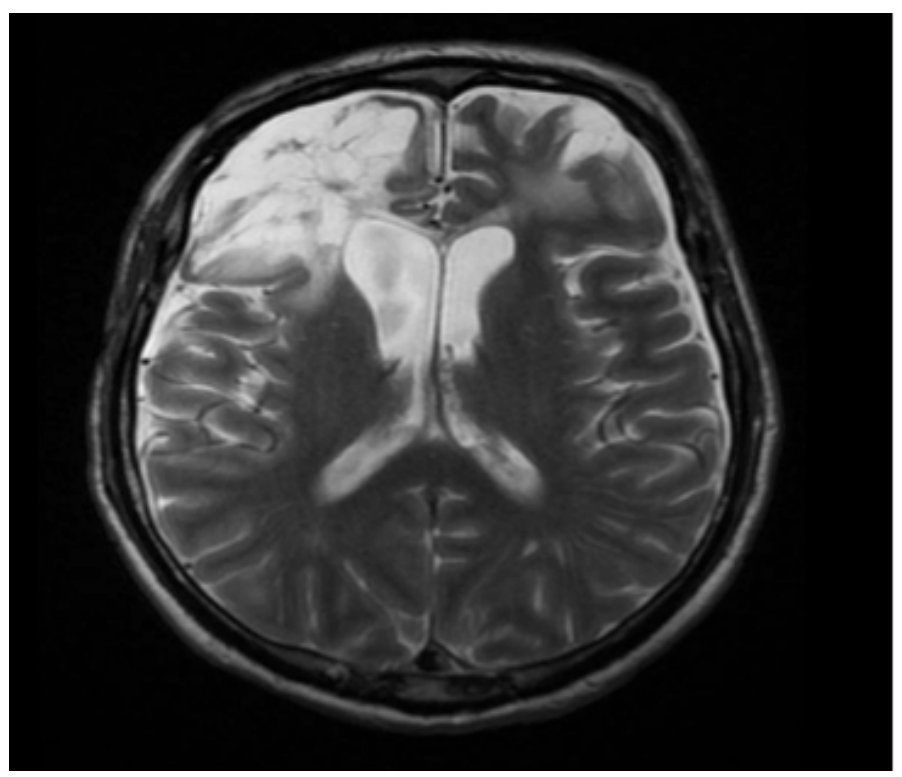

Resim 1. Hastada beyin MR'da akut-subakut enfarktla uyumlu alanlar

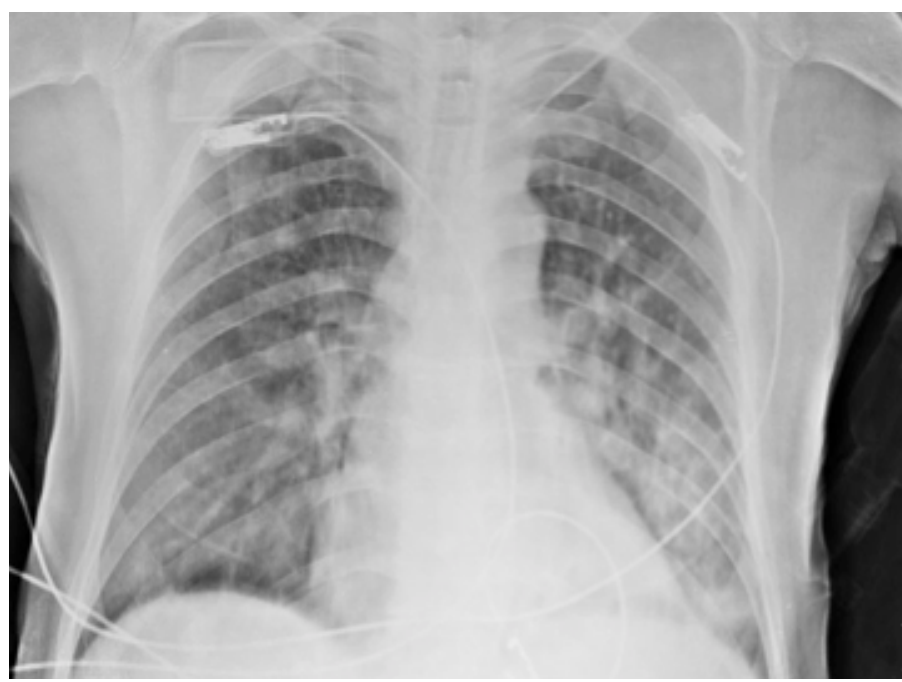

Resim 2. Hastanın yatışının 2. günü çekilen PA akciğer grafisi 


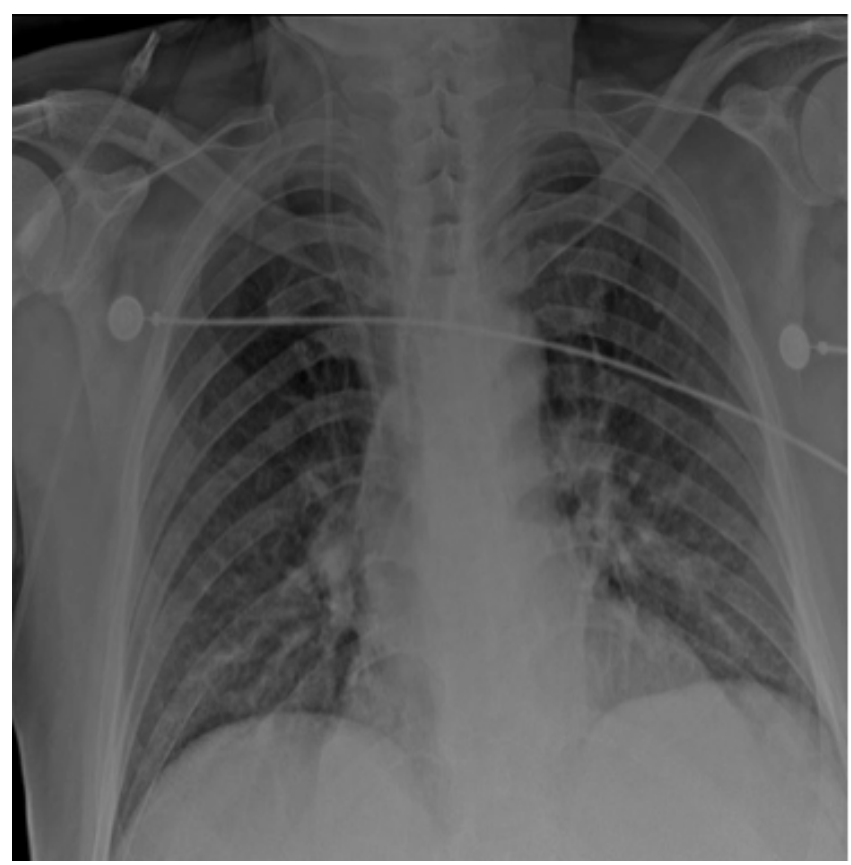

Resim 3. Hastanın tedavi sonrası PA akciğer grafisi

\section{Tartışma}

Pnömokokal menenjitler otit, sinüzit veya mastoidit gibi infeksiyon odaklarından komşuluk yoluyla veya etken bakterinin hematojen yolla santral sinir sistemine ulaşması sonucu gelişebilir $[2,4]$. Penisiline dirençli pnömokok suşlarının tedavisinde üçüncü kuşak sefalosporinler tercih edilir. Pnömokoklardaki penisilin direnci Klinik ve laboratuar standartları enstitüsü (CLSI) tarafından menenjit izolatları için MiK $\leq 0,06 \mu \mathrm{g} / \mathrm{ml}$ olanlar duyarlı, MiK $\geq 0,12 \mu \mathrm{g} / \mathrm{ml}$ olanlar dirençli olarak belirlenmiştir [5]. Pensiline dirençli pnömokok suşları varsa (MiK değeri MiK $\geq 0,12$ ) bu durumda tedaviye vankomisin eklenmesi önerilir [2,5].

Sunduğumuz olguda penisilin MiK değeri 0,047 mg/L idi. DuyarIı bir suş olmasına rağmen hastanın genel durumunun aniden bozulması, hastada septik bir tablo gelişmesi üzerine mevcut meropenem tedavisine devam edildi. Hastada tedavi sonrası komplikasyon olarak serebral enfarktüs geliştiği saptandı.

Pnömokok menenjitine bağlı olarak intrakraniyal ve sistemik komplikasyonlar gelişebilir. Pnömokok menenjitiyle ilişkili başlıca intrakrakraniyal komplikasyonlar; difüz beyin ödemi, hidrosefali, arteriyel ve venöz serebrovasküler komplikasyonlar, spontan intrakraniyal hemorajiler (vaskülitle ilişkili olup subaraknoid veya intrakraniyal kanama şeklinde olabilir), myelite bağlı akut spinal kord disfonksiyonu, iştitme kaybı, piyojenik ventrikülittir. Başlangıçta altta yatan kronik debilite hastalığı olanlar, düşük Glaskow koma skoru olanlar, başvuru esnasında fokal nörolojik defisiti olanlar, BOS'da lökosit sayısı düşük olanlarda menenjitle ilişkili intrakraniyal komplikasyon gelişme riski daha fazladır [4].
Sunduğumuz olguda BOS'da lökosit sayısı bakteriyel menenjitlerin aksine düşüktü, hastada daha önceden kafa kaidesi kırığı ameliyatı olma ve menenjit geçirme öyküsü vardı. BOS'da protein oranı yüksek ve ESH yüksekti, bu nedenlerle hastamızda komplikasyon olarak akut/subakut enfarktüs gelişmiş olabilir.

Sato ve ark. [6] altı yaşındaki pnömokok menenjiti olan bir erkek hastada BOS'da iki hücre olduğunu bildirmişlerdir. Olguda BOS ve kan kültüründen pnömokok izole edilmiştir. Bizim olgumuzda da BOS'da az sayıda lökosit görülmesine rağmen, kültürde pnömokok üremiştir.

Kastenbauer ve ark. [4]'nın pnömokok menenjitli 87 erişkin hastada yaptıkları çalışmada menenjitle ilişkili intrakraniyal komplikasyonların hastaların \%75'sinde, sistemik komplikasyonların ise \%38'inde geliştiği bildirilmiştir. Difüz beyin ödemi \%29 olguda, hidrosefali \%16 olguda, arteriyel serebrovasküler komplikasyonlar \%22 olguda, venöz serebrovasküler komplikasyonlar \%9 olguda, spontan intrakraniyal kanamalar \%9 olguda, işitme kaybı yaşayan hastaların \%25'inde rapor edilmiştir. Bizim olgumuzda da komplikasyon olarak serebral enfarktüs gelişti.

Schut ve ark. [7] yaptıkları gözlemsel kesitsel çalışmada 696 menenjit hastasının 174'ünde serebral infartüs geliştiğini bildirimişlerdir. Serebral enfarktüs pnömokok menenjiti gelişen 352 hastanın 128'inde (\%36), meningokok menenjiti olan 257 hastanın ise 22'sinde (\%9) serebral enfarktüs geliştiğini bildirmişlerdir. Serebral enfarktüs gelişen hastalarda risk faktörlerinin ileri yaş, altta yatan otit ve/veya sinüzit gibi predispozan durumlar ve immünsupresif durum olduğu bildirilmiştir. Bu çalışmada, ayrıca Glaskow koma skorunun düşük olması, BOS'da lökosit sayısının düşük olması, eritrosit sedimentasyon hızının yüksek olmasının da serebral enfarktüsle istatistiksel olarak anlamlı ilişki gösterdiği belirlenmiştir. Sunduğumuz olgumuzda da başlanğıç Glaskow koma skorü, BOS hücre sayısı düşüktü, ancak eritrosit sedimentasyon hızı normal sınırlarda idi

Bodilsen ve ark. [8] Danimarka'da 152 toplum kaynaklı pnömoni epizodunda 22 (\%14) inme epizodu (15'i iskemik, 3'ü hemorajik, 4'ü kombine ) tanımlamıştır. Shultz ve ark. (6) çalışmalarının aksine bu çalışmada inme gelişimi ile yaş ve ateroskleroz arasında ilişki olamdığı, ancak inme gelişiminin yüksek hastane mortalitesi, istenmeyen sonuçlar ve hayatta kalanlarda uzun süreli sekellerle ilişkili olduğu bildirilmiştir.

Kafa kaidesi kırığı olan hastalarda pnömokok aşısı uygulanmasının pnömokok menenjiti görülme sıklığını anlamlı oranda azalttığı bildirilmiştir [3,9]. 
Sonuç olarak; sunduğumuz olguda olduğu gibi kafa kaidesi kırığı ameliyatı olan ve bakteriyel menenjit saptanan hastalarda mevcut olan bilinç değişikliklerinin eş zamanlı serebral enfarkta da bağlı olabileceği akla gelmeli ve uygun görüntüleme yöntemleri yapılmalıdır. Ayrıca bu hasta grubunda rekürren menenjit gelişimini önlemek için pnömokok aşısının uygulanması da uygun bir yaklaşımdır.

\section{Maddi Destek ve Çıkar İlişkisi}

Çalışmayı maddi olarak destekleyen kişi/kuruluş yoktur ve yazarların çıkara dayalı bir ilişkisi yoktur.

\section{Kaynaklar}

1. Parlak M. Akut bakteriyel menenjitler. Toplumdan edinilmiş enfeksiyonlara pratik yaklaşımlar sempozyum dizisi kitabı 2008; s.151-64.

2. Gerald L. Mandell, John E. Bennett, and Raphael Dolin. Acute meningitis. In: Mandell, Douglas, and Bennett's Principles and Practice of Infectious Diseases, Seventh Edition 2010; 1189-229.

3. Cohen-Inbar O, Kachel A, Levi L, Zaaroor M. Vaccination as primary prevention? The effect of anti-pneumococcal vaccination on the outcome of patients suffering traumatic skull base fractures. J Neurosurg Sci 2015; PMID:26082383.
4. Kastenbauer S, Pfister HW, Pneumococcal meningitis in adults: spectrum of complications and prognostic factors in a series of 87 cases. Brain 2003; 126: 1015-25.

5. Gözel Mg, Elaldı N, Engin A, Bakır M. Toplum kökenli menenjit gelişen hastalarda beyin omirilik sıvısından izole edilen Streptococcus pneumoniae suşlarında penisilin duyarlılığının ve ampirik antibiyotik seçiminin değerlendirilmesi. ANKEM Derg 2011; 25: $263-6$.

6. Sato R, Nasu M, Yagi R, Kitahara, Y. Streptococcus pneumoniae meningitis without pleocytosis of the cerebrospinal fluid. Am J Emerg Med 2016; 34: 941.e1-941.

7. Schut ES, Lucas MJ, Brouwer MC, Vergouwen MD, van der Ende $A$, van de Beek D. Cerebral infarction in adults with bacterial meningitis. Neurocrit Care 2012; 16: 421-7.

8. Bodilsen J, Dalager-Pedersen M, Carl Schønheyder H, Nielsen $\mathrm{H}$. Stroke in community-acquired bacterial meningitis: a Danish population-based study. Int J Infect Dis 2014; 20: 18-22.

9. Alari A, Chaussade H, Domenech De DM, et al. Impact of pneumoccocal conjugate vaccines on pneumoccoccal meningitşs case in France between 2001 and 2014: a time series analysis. BMC Med 2016; 14: 211. 